\title{
Ethnography and Democracy: Texts and Contexts in the United States in the 1990s
}

\section{Carol J. Greenhouse*}

In some respects, the decade of the 1990s was an anachronism even in its own times. The crossed preoccupations with "posts" (postmodern, postcolonial, postindustrial, post-Marxist, among others) and "precedents" (the impending millennium) made it paradoxically easy to miss the moment. The debates over constructionist and interpretivist approaches to ethnography and the cultural analysis of texts makes a case in point. Such theories gained widespread acceptance in the humanities and social sciences in the 1980s and 1990s (if always as counter-canons), but they never worked free of the persistent criticism that they lacked attention to power. What and where was this "lack"? In this Essay, I will suggest that it was not in the method, but in the object of inquiry - the public sphereas the civil rights era yielded to neoliberalism, and as the lines of confrontation took form, as both partisan divisions within the federal government and competition among the branches. Advocates and critics of constructionism and interpretivism alike took for granted these pragmatic circumstances; however, a reflexive analysis of interpretivism reveals assumptions about realism and readership (among other things) specific to the politics of that time and place. Interpretivism's power for projects of cultural critique is a power of association with the textual genres, tropes, and institutional practices of legal activism and citizens' movements of the previous generation-the civil rights era of the 1950s and 1960s. This remains part of their power, but in the places in the

* Carol J. Greenhouse is Professor of Communication and Culture, Anthropology, and Gender Studies at Indiana University. My thanks to Austin Sarat and Jonathan Simon for their invitation to contemplate the relationship of cultural studies and sociolegal studies in such a hospitable setting, and to colleagues at the Yale Symposium - participants and editors alike. Thanks, too, to student and faculty colleagues whose comments on earlier versions or portions of the essay in seminars at the Ecole des Hautes Etudes en Sciences Sociales (Paris), Indiana, Princeton, and Purdue, as well as at the annual meeting of the American Anthropological Association in Chicago (1999), helped shape the present essay. In those contexts, special thanks to Joëlle Bahloul, Richard Bauman, James Boon, John Bowen, Don Brenneis, Andrew Buckser, Nahum Chandler, Jean Heffer, Robert Ivie, Emily Martin, Phil Parnell, and Lawrence Rosen. 
United States where ethnographers work, the law has moved on, and its power is recognizable in interpretative ethnography primarily in traces of that association, which are evident as nostalgia, irony, and allegory, among other things.

The 1990s are an ideal context in which to explore such issues, because the new proximity of cultural studies and legal studies brings these very questions to the fore, highlighting recent transformations of the state from standpoints afforded by the emergence of new forms of difference. In this Essay, I concentrate on the horizons where the "crisis of representation"1 implies both a commitment to social portraiture and democratic aspiration-indeed, it is political struggle that defines key stakes in social portraiture. My artifacts are texts of the 1990s from the three genres that give primary attention to "representation" in this double sense (the semiotics and politics of representation): ethnography, literature, and law. I explore these for their respective constructionist strategies and their mutual points of contact and strain. I focus especially on their literariness in relation to each other; indeed, my main interpretive claim is that these genres' literariness defines them as democratic practices in specific ways. Along this critical horizon in the United States, cultural studies and legal studies are adjacent practices specific to the context of their creation. This means that part of the ethnographic value of textual interpretation lies in its access to political and social contests in which the state is implicated as agent, addressee, or arena. Correspondingly, part of the value of contemporary ethnography is in its implicit demarcation of a relationship between textual forms and the limits of social inclusion.

The exchanges between cultural studies and legal studies over the last ten years or so are not merely an example of promising dialogues that have emerged between disciplines on some neutral ground, but evidence from the heart of the matter. The matter is social justice. In key respects, the cultural analysis of texts is predicated on a tacit critique of liberalism's limits, especially in the neoliberal context emerging in the 1990s. This can be seen most vividly, I will argue, in contexts where neoliberalism defeats the legislative expansion of rights by rendering its poetics moot. In the United States of the 1990s, as key elements of liberalism and its critique faded away (or were pushed away) from the legislative arena, they became objects of interdisciplinary dialogue and debate. Academics called for attention to text and narrative precisely at the junctures where mainstream political discourse foreclosed an older justice discourse anchored in the common sense notions of relief. ${ }^{2}$

1. George E. Marcus \& Michael M.J. Fischer, A Crisis of Representation in the Human Sciences, in ANTHROPOLOGY AS CULTURAL CRITIQUE: AN EXPERIMENTAL MOMENT IN THE HUMAN SCIENCES 7, 7 (1986).

2. For a discussion of nineteenth- and early twentieth-century legal liberalism, see Michael Grossberg, The Politics of Professionalism: The Creation of Legal Aid and the Strains of Political Liberalism in America, 1900-1930, in LAWYERS AND THE RISE OF WESTERN POLITICAL LIBERALISM 
State nationalism entails a classic story-line: a "nationalist historicism that assumes that there is a moment when the differential temporalities of cultural histories coalesce in an immediately readable present." ${ }^{.3}$ That story-line is partially endorsed by the classic conventions of human sciences and is partially an object of their critique. The conventions presuppose that collective identities are large-scale projections of individual affinity and character; that law is an expression of identity and a resource of socialization; that identities might become a fixed, coherent set of choices and standards over time. Such assumptions- "the dream of a unified field," to borrow poet Jorie Graham's phrase 4 -are deeply inscribed in liberal thought and its social science extensions, offering a certain (sometimes inspiring, sometimes chilling) poetics of democratic aspiration. Scholars who are critical of this vision elaborate the incommensurability of collective identities, the difference between selfidentity and identification by others, and the place of law in fragmenting horizons of identification and consolidating collective interests as identifications. Such critics explore the mythical status of the nation itself, as well as the ways in which that myth supports patterns of exclusion, marginality, and invisibility. They propose the possibility that "culture" might be both a categorical displacement of politics and an affirmation of the possibility of solidarity and innovation.

These two formulations of the constitution of individual and collective identities in the nation are not mutually exclusive; they are different registers in the analysis of the United States as a diasporic site in which the (so-called) national culture monopolizes the terms of identification but not their significance. ${ }^{5}$ Thus, reflecting on the contemporary situation of Asian Americans, Lisa Lowe writes:

Culture is the terrain through which the individual speaks itself as a member of the contemporary national collectivity, but culture is also a mediation of history, the site through which the past returns and is remembered, however fragmented, imperfect, or disavowed. Through that remembering - that recomposition-new forms of subjectivity and community are thought and signified. ${ }^{6}$

Constructivism and interpretivism are emergent from the fault lines between liberal and conservative approaches to equality and social justice, but it is important to note from the outset that these approaches need not inevitably belong to either side of the debate. For classic liberals,

309 (Terrence Halliday \& Lucien Karpik eds., 1997).

3. HOMI K. BHABHA, DissemiNation: Time, Narrative and the Margins of the Modern Nation, in THE LOCATION OF CULTURE 139, 152 (1994).

4. JORIE GRAHAM, The Dream of the Unified Field, in THE DREAM OF THE UNIFIED FIELD: SELECTED POEMS, 1974-1994, at 176 (1995).

5. See AVtar Brah, Cartographies of Diaspora: CONTESTING Identities (1996).

6. Lisa Lowe, The Power of Culture, 1 J. ASIAN-AM. STUD. 5, 19 (1998). 
constructivism lends itself to pluralism, individual choice, and a methodology of color blindness, as solidarity is deconstructed to expose individual interests and choices. For conservatives, though, constructivism exposes key social categories and mainstream claims (race, for example) as empirically falsifiable. Both groups (and these binary categories are purely heuristic, as is perhaps already clear) regard identity as originating in antagonisms and displacements within the nation. This in itself is problematic, as Nikhil Pal Singh makes clear:

If we are ever to consider going beyond multiculturalism, we must first assess in a more thoroughgoing manner just what it has actually meant in recent history (and what it might mean in the future) to rely upon the U.S. nation-state as a stable container of social antagonisms, and as the necessary horizon of our hopes for justice.?

Or, to borrow Joan Scott's cautionary phrase on a related point: "It is not a happy pluralism that we ought to invoke." Indeed, it is not: Constructivism instead commits one to an ethnographic project of considering the fields of encounter where the term "identity" answers a question of political subjectivity. Such encounters are likely to be along lines that are uneven, fragmentary, and sometimes obscure. We should not invoke a "happy pluralism" because, as we shall see, the state, the nation, citizenship, and culture constitute different discursive topographies of possibility and contestation, not a unified field internally differentiated by sector or scale.

In the 1990 s, ethnography, literature, and law were most alike in their attention to inequality and their common commitment to anti-racism, but they differed in other key respects: their analysis of difference and the potential agencies of justice, the limits of law, and the place of the United States in a transnational order, among others. These differences give me my main themes. In the realm of fiction, I focus on works by authors who write explicitly about racism. ${ }^{9}$ Such works have been a flourishing segment of the U.S. fiction market, in terms of the range of books (many

7. Nikhil Pal Singh, Culture/Wars: Recoding Empire in an Age of Democracy, 50 AM. Q. 471, 472 (1988).

8. JEAN Wallach SCOTT, The Sears Case, in GENDER AND the POlitics of HISTORY 167, 176 (1988).

9. I draw especially on the following books: SANDRA CISNEROS, THE HOUSE ON MANGo STREET (1994); SANDRA CisNeros, WoMAN Hollering CreEK (1991); Christina GarCIA, DrEAMING IN

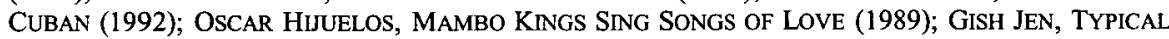
AMERICAN (1991); DAVID WONG LOUIE, PANGS OF LOVE (1991); JAIME MANRIQUE, LATIN MOON IN Manhattan (1992); Paule Marshall, Praisesong for the Widow (1983); Paule Marshall, The Timeless Place, the Chosen People (1969); Toni Morrison, Beloved (1987); TONI MORRISON, THE BLUEST EYE (1970); TONI MORRISON, JAZZ (1992) [hereinafter MORRISON, JAZZ]; DARRYl PINCKNEY, High COTTON (1992); LESLIE MARMON SILKo, CerEMONY (1977); AMY TAN, The Joy LuCK Club (1989); AMY TaN, ThE KITChen God's Wife (1991); Alfredo VeA, JR., LA Maravilla (1993); Alice WALKer, POSSESSING THE SECRET OF JoY (1992) [hereinafter WaLKER, SECret of JoY]; Alice Walker, TEMPle of My Familiar (1989); SYlvia WatanaBe, Talking TO THE DEAD (1992). 
by new authors), their critical acclaim, and their sales. There has also been a surge in publication of ethnographic accounts of American experience, particularly in inner city areas characterized by ethnic and racial diversity and, in general, sustained poverty. My legal text is the Americans with Disabilities Act of 1989 (ADA), ${ }^{10}$ a harbinger of the contents of and contests over both the failed Civil Rights Act of $1990,{ }^{11}$ and the Civil Rights Act of $1991 .^{12}$

The rest of my discussion is in three main parts. Part One poses the central question of the Essay (regarding the historical and political specificity of constructionist approaches to texts) in relation to the ethnography of the United States. I begin there partly because I am an ethnographer, but also because the problems and politics of realism (which constructionism and interpretivism tacitly address) are most clear in this hyper-realistic genre. In Part Two, I focus on narrative and narrative structure, concentrating on a comparison of ethnography and fiction. In Part Three, I extend that comparison to a detailed discussion of the congressional hearings that led to the ADA. These texts are connected by their respective constructions of federal power. They are divided primarily by their very different expectations of law in practice.

\section{U.S. ETHNOGRAPHY: \\ BACKGROUND AND PROSPECTS For NEW BEGINNINGS}

The ethnography of the United States is a vast literature, but it is strikingly resistant to self-reference as a literature. Knowing how to read such texts cumulatively is never obvious, since how things "add up" across texts implies some correspondence to knowledge of real-life processes "on the ground." In this sense, cumulative reading is itself an ethnographic practice of sorts, and its absence is noteworthy in relation to this genre. In the case of U.S. ethnography, as Hervé Varenne has convincingly argued, cumulative reading founders under the hectoring of constant disruption by anthropologists' ideological attachments to the notion of the United States as a culture of individualists. ${ }^{13}$ In practice, the ethnography of the United States is a large collection of isolated works about local communities and institutions, which pays relatively little attention to the translocal dimensions of social life and contains few works of a comparative nature.

The localism in the U.S. ethnographic field is no doubt a hallmark of

10. 42 U.S.C. $\S \S 12,101-12,213$ (Supp. V 1993)

11. Two bills comprised the 1990 anti-discrimination legislation: H.R. 4000, 101 st Cong. (1990), and S. 2104, 101 st Cong. (1990).

12. Pub. L. No. 102-166, 105 Stat. 1071 (1991) (codified as amended at scattered sections of 2 U.S.C., 29 U.S.C., and 42 U.S.C.).

13. See Hervé Varenne, Collective Representation in American Anthropological Conversations About Culture: Culture and the Individual, 25 CURRENT ANTHROPOLOGY 281 (1984). 
anthropology's tradition of studying village life, with the American "case" being a somewhat mimetic exercise. But in the context of ethnography's practice within the United States, this localism can also be read as a sign of the times in which it took shape as a genre. Arising in the civil rights era of the 1960s and its immediate aftermath, the localist emphasis of ethnography reflected the Civil Rights Movement's attention to "the local" as the site of customary (discriminatory) practices. But the localism is deceptive-or rather, it is a localism constructed by federal architects, for a national audience.

The community study, not too fashionable in the ethnography of elsewhere nowadays, is still very much in vogue among American anthropological authors who write about the United States. ${ }^{14}$ These are studies of place: diaspora and arrival, ethnic neighborhoods, multiracial settings of various kinds. The localism of community tends to emphasize the marginality of communities-obviating critical aspects of context and historical process. By contrast, the ethnography of postmodernity (of institutions and media, for example) - the other major ethnographic register for the United States - tends to personify hegemony, ideology, and discourse in ways that displace questions of agency, and, indeed, location in favor of the "new" and the now.

The possibility of bridging this divide tends to be concealed by conventions of scale. Those conventions are based in part on illusions imported into ethnography from the social distances that divide actual people in their everyday encounters: distances that divide institutions from the individuals they serve, governments from citizens, corporations from consumers, and so forth, yielding illusions capable of dividing even two people who are face-to-face. This appearance of incommensurability hints at other ethnographic domains that are not hidden, but simply out of the usual range of ethnographers' attention: for example, the employees of large scale institutions and government. Questions of agency-by which I mean the relevance of individuals' actions-should not be suspended in the face of such conventions of scale, nor in the silences that sometimes give rise to them.

\section{HOW DOES ETHNOGRAPHY WORK?}

U.S. community studies from the 1990s are books about American cities, neighborhoods in trouble or in ruins. They are stories of social distress, sometimes extreme distress, as well as resilience and survival. They are immigrant stories of successes and failures; they are stories of lives hemmed in by racism and poverty, problematic access to needed resources, intergenerational tensions, and pervasive uncertainty. They

14. See, e.g., MiCAela di LeONARdo, Exotics at HomE: ANTHRopologists, Others, AMERICAN MODERNITY (1998); Michael Moffat, Ethnographic Writing About American Culture, 21 ANN. REV. ANTHROPOLOGY 205 (1992). 
relate gripping human dilemmas, written in ways that register direct appeals to readers' capacities for empathy and civic resolve. They emphasize the details of individual situations. The works tend to be strongly contained by their attention to local detail and the authorizing details of ethnographic rapport. Their citations to other ethnographic works (even in the same city) are rare, with the exception of ethnic communities, whose origins are often reflected in a bibliography through references to other studies of their homelands.

Even while they tend to dissolve the time and space around the study site, however, community studies in the United States are cast as direct appeals to a general audience. I will focus on this feature of their narrative structure. In a prologue, or epilogue, or both, the authors invite readers to envision this community in some affirmative relation to the society at large. Tolerance, economics, and democracy are the touchstones of such visions. Bracketed by prefaces and endings in these terms, the moves from opening to main text and from main text to closing provide a pair of performances-one from a personal discourse to a discourse of discipline; the other from discipline to personal hope. These are performances of conversion, accomplished through the works' narrative structures. The conversion is to citizenship: the ethnographer's identification with readers (prologue or preface), the ethnographer's performance of learning and liberal tolerance (the main text), the ironically hopeful endings envisioning democracy's increase (the conclusion, final paragraph, or epilogue).

Since the market for ethnographic writing is not (or not yet) a general market, such narrative stagings would seem to be for the benefit of the anthropological profession, or our students. What does it mean, then, that as anthropologists we address each other as citizens, as if to create for other anthropologists a mirror of our own craft in the convictions of an imaginary general public?

The answer depends on what kind of act reading is. The community studies-written to citizens as if they were not anthropologists-invite readers to experience a break between the "real" world (in which anthropological knowledge is true but arcane) and an imagined world in which anthropological knowledge would be valued for its relevance to urgent social problems. Here is an example from the closing paragraphs of Philippe Bourgois's In Search of Respect:

I hope to contribute to our understanding of the fundamental processes and dynamics of oppression in the United States.... Highly motivated, ambitious inner-city youths have been attracted to the rapidly expanding, multi-billion-dollar drug economy during the 1980s and 1990s precisely because they believe in Horatio Alger's version of the American Dream .... 
"Mainstream America" should be able to see itself in the characters presented on these pages and recognize the linkages. The inner city represents the United States' greatest domestic failing, hanging like a Damocles sword over the larger society .... From a comparative perspective, and in a historical context, the painful and prolonged self-destruction of people like Primo, Caesar, Candy, and their children is cruel and unnecessary. There is no technocratic solution. Any long-term paths out of the quagmire will have to address the structural and political economic roots, as well as the ideological and cultural roots of social marginalization. The first step out of the impasse, however, requires a fundamental ethical and political reevaluation of basic socioeconomic models and human values. ${ }^{15}$

Bourgois's epilogue, written after a visit back to the neighborhood as the book went to press, takes a cinematic form, listing each character and place, with accompanying notes to bring the action up to date. They are the notes of a nightmare. In the book's closing lines, he goes farther, presenting a moving testimony of his own distress:

Witnessing [people's situations] during the few weeks that I spent back in El Barrio in the spring and early summer of 1994 made me realize I had lost the defense mechanisms that allow people on the street to "normalize" personal suffering and violence. For example, I still cannot forget the expression of the terrified, helpless eyes of the five-year-old boy who was watching his mother argue with a cocaine dealer at 2:00 a.m. in the stairway of a tenement where Primo and I had taken shelter from a thunder shower on my second night back in the neighborhood. Primo shrugged when I tried to discuss the plight of the child with him. "Yeah, Felipe, I know, I hate seeing that shit too. It's wack." 16

I draw on Bourgois's text because he makes explicit what is implicit in many similar contemporary ethnographic works about the United States. In the book's double closure, Bourgois specifies two moments of loss. The first is the public one in the conclusion to the monograph: "There is no technocratic solution." ${ }^{\prime 7}$ The second is the private one in the personal epilogue: "I had lost the defense mechanisms that allow people on the street to "normalize' violence." 18 And then at the last instant, in a powerful moment of identification with the child, he aligns these as a problem of knowledge that remains his (not Primo's) - and now, ours. His text figuratively positions the reader-or rather, he makes use of what is

15. Philippe Bourgois, In SEARCh OF RESPECT: SelLING CRACK IN THE BarRio 326-27 (1996).

16. Id. at 337 .

17. Id. at 326 .

18. Id. at 337 
inevitably the reader's literal position, holding the book. The lines yield a strong impression of this terrified child, staring back from the page into the reader's eyes. The book's conclusion also has a performative aspect, in that the conclusion is not just in words, but also in the arrayed distinctions among silences from which the reader cannot avoid choosing: indifference, numbness, terror, or excessive knowledge. The book ends, then, by encompassing the reader's very presence--through this ambiguous silence and the inescapability of choosing-within the scene itself. Asking, "What does this book mean?" becomes the same as asking, "What kind of person am I?"

Bourgois's text is a fine example of the genre, which relies on the structural form of allegory:

The immersion of allegory has to clear away the final phantasmagoria of the objective and, left entirely to its own devices, re-discovers itself, not playfully in the earthly world of things, but seriously under the eyes of heaven. And this is the essence of melancholy immersion: that its ultimate objects... turn into allegories, and that these allegories fill out and deny the void in which they are represented, just as, ultimately, the intention does not faithfully rest in the contemplation of bones, but faithlessly leaps forward to the idea of resurrection. ${ }^{19}$

I draw on Benjamin to make the point that while Bourgois's study-like other community studies - is intensely local, the allegorical form does the work of evoking "the economy of the whole." 20 The author's formal address to other anthropologists and their students commits these pages to a tacit transnationalism more than its contents or argumentation does.

The narrative structure of Bourgois's book, in other words, announces the social and political aspirations of the work, and situates the political in relation to the social at the point where readers are induced to reinterpret their own silence - -inevitably, the silence of reading in solitude - as a field of knowledge and responsibility. These structural dynamics are legible, though, only to the extent that one brings to the book some broader knowledge of its times. The construction of knowledge as both moral and political is crucial to the book's ethical charge: ${ }^{21}$ The challenge to defend ethnography's relevance in terms of ethical engagement is a tacit reference to a specific political and economic order. Only a knowing reader is capable of accepting this challenge and offering such a defense. Importantly, however, the empirical realm of that reader's reflection is itself placed outside the book, an exterior world constructed in the book's

19. WALtER BENJAMIN, THE ORIGIN OF GERMAN TRAGIC DRAMA 232-33 (John Osborne trans., Verso 1998) (1963).

20. Id. at 234; accord id. at 186.

21. See id. at 230-31 (discussing of the ethical implications of knowledge in the tragic context). 
final pages as the domain of failed solutions within the liberal order. Other community studies share this book's allegorical structure, lending them the form of a morality play in which the reader is confronted at the last minute with the possibility that tragedy might be averted if ethnographic knowledge can be redeemed as democracy. ${ }^{22}$ I call this structural feature "the democratic envoi"- -the happy ending that is the sign that the book should be read in time-this, indeed, is the time of the nation. ${ }^{23}$ The following examples of democratic envois are drawn from recent ethnographies of New York City:

[1] Thus, immigrants-legal or not--breathe new life into an American dream that has proven elusive to many native-born. The transformation of successful immigrant groups into "model minorities" goads Americans in general, and less successful minority groups in particular, into believing, much as immigrants do, that success is more the product of individuals' hard work and sacrifice than of differences in their levels of education and economic resources. Imported rugged individualists and American dreamers, immigrants buttress the foundational ideology, the primal myths of Americana. In sum, though they are often accused of alien beliefs and practices, they fundamentally contribute to the nation's cultural reproduction. ${ }^{24}$

[2] Since they are saving less money for the future and the return home, their original monetary goal remains illusive, and they stay on the host country for another year and yet another. As more and more immigrants go through this process, a community of sojourners is transformed into a community of settlers.

This scenario will likely hold for Brazilians as they become a permanent ingredient in New York's vibrant ethnic medley. Having been sojourners, many will turn settlers. They will become true transnationals. They will continue to live in the United States, but they will not abandon Brazil; they will not stop thinking of themselves as Brazilians or stop going home on visits to see family and friends; they may even retire in their native land. But like so many immigrants to these shores before them, Brazilians will see their lives and future as intimately tied to the fortunes and future of their adopted home. ${ }^{25}$

\footnotetext{
22. Ralph Ellison distinguishes tragedy from the absence of solutions, referring to the latter as the "blues." RALPH ElLISON, SHADOW AND ACT 94 (1964).

23. See HOMI K. BHABHA, supra note 3, at 139.

24. SARAH MAHLER, AMERICAN DREAMING: IMMIGRANT LIFE ON THE MARGINS 233 (1995).

25. MAXINE MARgolis, LITTLE BRAZIL: AN ETHNOGRAPHY OF BRAZILIAN IMMIGRANTS IN NEW YORK CITY 275 (1994).
} 
[3] Small business activities today are a symbol, perhaps the key symbol, of Korean American identity and success. But today, some Korean immigrants are considering the warning from the overconfident rabbit in the race with the turtle. They find it necessary to reassess the Korean American dream. As they experience life in America, Korean Americans create new identities, new cultural forms, and new ideologies. Ultimately, through these acts of creation, they reshape American dreams. ${ }^{26}$

[4] With the tense racial and ethnic climate in the United States today, the slogan "a second Chinatown" might well cause nonChinese to fear that the Chinese are "taking over" and produce resentment. Anti-Chinese feeling has indeed been expressed in recent years as more and more Chinese and Asians have migrated to Queens. But no part of Queens is a second or third Chinatown. Queens is a world town for those people who come from many parts of the world to contribute, like the Chinese, their talents and strengths to make this diverse community more prosperous, more beautiful, and more peaceful. ${ }^{27}$

[5] Nothing is impossible if we believe that people can change. ${ }^{28}$

Such patterned flourishes establish a break just inside the books' back covers between the present (the manifest subject of the monograph) and the future. Ethnographic narrative structure projects concern for the future both in the organization of the ethnographic substance and (more especially) in the sharply drawn juxtaposition between the book's contents and the fantasy version of its reception. (By "fantasy" I do not intend a dismissal, but an indication of how an ambiguous power gap between subjects, author and readers, is incorporated into the text via a substitution, as a time gap.) Prologues are less patterned (and less concise), but they stage a similar demonstration of ethnographic discipline as the personal narrative of the circumstances of field research gives way to the scientific discourse of the main text.

By methods such as these, the narrative structure of the monographs is organized around intention and disappointment in the democratic public sphere, though their substance is oriented elsewhere, generally towards assimilation. ${ }^{29}$ Read cumulatively, the refrain is striking: the snares of the

26. Kyeyoung Park, The Korean AMERICAN DREAM: IMMIGRANTS ANd SMALl Business IN NEW YORK CITY 206 (1997).

27. HSIANG-Shui ChEN, ChINATOWn No MORE: TAIWAN IMMIGRANTS IN CONTEMPORARY NEW YORK 263 (1992).

28. ROGER SANJEK, THE FUTURE OF US ALL: RACE AND NEIGHBORHOOD POLITICS IN NEW YORK CITY 393 (1998).

29. See Bill ashCroft, Gareth Griffiths \& Helen Tiffin, The Empire Writes Back: THEORY AND PRACTICE IN POSTCOLONIAL LITERATURES (1989). 
American dream and the widening income gap within racial and ethnic communities. But the word "refrain" is not quite right, here. In twelve recent books about New York City, for example, the refrain is only a passing reference in each book; it becomes a refrain only in the context of a cumulative reading. ${ }^{30}$ It is only in the repetition of passing references, across New York City and elsewhere, that a window opens onto key developments of the 1980s and 1990s, that a glance can become the timespace of a gaze: The ethnographic problem ultimately emerges from the increasing gap between the rich and the poor; the significant decline in real wages; the resegregation of U.S. cities and suburbs; the feminization of poverty; the criminalization of identity; the expansion of poverty among the full-time employed; the lessened impact of education on personal income prospects; the political imperatives linking welfare to work, and immigration to costs; the shift of employment in the major cities from manufacturing into the service sector, and into the suburbs; the high rates of uninsured and under-insured in the cities, and the crisis of self-care-these are some of the developments that surface in the spaces within the monographs, and (even more obviously) between them, as well as between the ethnographies, fiction, and civil rights law.

\section{HOW DO NOVELS WORK? $?^{31}$}

If ethnography makes for powerful reading, its power is contingent on knowing readers' ability to break through the monograph's strategies of containment. The narrative structure of the monographs stages the act of reading itself as the precondition of power, in Hannah Arendt's sense of this word:

Power is actualized only where word and deed have not parted company, where words are not empty and deeds not brutal, where words are not used to veil intentions but to disclose realities, and deeds are not used to violate and destroy but to establish relations and

30. In addition to those sources cited elsewhere in this Essay, the monographs I draw on are Karen MCCarthy Brown, Mama Lola (1991); Steve Gregory, Black Corona (1998); PhILIP KasinItZ, CARIBBEAN NEW YORK (1992); MICHEL LAGUERRE, AMERICAN OdYSSEY (1984); MOSHE SHOKEID, CHILDREN OF CIRCUMSTANCES (1988); BONNIE URCIUOLI, EXPOSING PREJUdICE (1996).

For further discussion of the impact of neoliberalism and globalization on the social life of New York City, see JANET ABU-Lughod, New York, ChICAGo, Los ANGELES: AMERICA's GLOBAL CITIES (1999); GREGORY, supra; SANJEK, supra note 24; Gregory, The Changing Significance of Race and Class in an African-American Community, 19 AM. ETHNOLOGIST 255 (1992). See generally SCOTT LASH \& JOHN URRY, ECONOMIES OF SIGNS AND SPACE (1994) (especially Part III). But see ABU-LUGHOD, supra, at 399 (discussing the risks of over-generalization, given the extent to which globalization affects cities in ways that appear to be specific to their situations).

31. Fredric Jameson, The Polmtical UnConscious 22 (1987) (quoting Gilles Deleuze \& Felix GuATTARI, ANTI-OEDIPUS 109 (1977)). Drawing on Deleuze and Guattari's question, "How does it work?" Jameson distinguishes between questions of meaning and questions of narrative technology. 
create new realities. ${ }^{32}$

Fiction's "essential gesture" 33 involves a different critique and a different formulation of critical agency. In comparison with the ethnographic literature, the novels of the 1990s are striking first for their abandonment of the optimism of the civil rights era and, more generally, "the ethnic success story." 34 The novels contemplate tragedy, or realize tragedy fully. Furthermore, the novels complicate difference by entwining color, ethnicity, class, and gender in ways that defy any singular set of identity categories; the community studies-which include narratives of rapport-highlight the bonds and barriers of gender, age, race, and ethnicity, and, to some extent, class. Novelists do not segregate their neighborhoods; they portray them as numerous "others," all unequally unequal.

Against the intentions of their authors, I believe, conventional modes of anthropological presentation tend to reinforce an essentialist view of difference-for example, by equating discrimination with identity, concentrating on the distinctive character of "ethnic" neighborhoods, and treating assimilation as culture loss. Further, in the ethnographic texts, color and/or national origin are treated as primary markers that define individuals within "their" groups, locally and temporally. The novels, on the other hand, often connect current American experience to other geographies and histories.

Ethnographies are organized by social field, their narrative breaks reserved for the transit to and from the monograph proper, just inside the preface or epilogue. Fiction offers abundant heteroglossia and narrative breaks. Shifting points of view, the interior presence of the narrator, frequent disjunctions of time and space - these devices clarify the authors' analyses of the unsteady environments of living, as well as their own claims to a place in the transnational circulation of postcolonial novel forms. ${ }^{35}$ Individuals are present in the novels, offering figurations of the varied modes of consciousness and the challenges of consciousness; of knowing who one is in others' eyes, of knowing oneself as "simultaneously the subject and object of the socio-historical process."

32. HaNNah ARENDT, The HuMAN CONDITION 200 (1998).

33. Nadine Gordimer, The Essential Gesture, in THE ESSENTIAL GESTURE: WRITING, POLITICS, AND PLACES 285 (Stephen Clingham ed., 1989).

34. Phyllis P. Chock, The Landscape of Enchantment: Redaction in a Theory of Ethnicity, 4 CULTURAL ANTHROPOLOGY 163 (1989).

35. See ASHCROFT, GRIFFTHS \& TiffIN, supra note 29; Firdous AZIM, THE COlONIAL Rise OF THE NOVEl (1993); JACQUELINE KAYE \& ABDELHAMID ZOUBIR, THE AMBIGUOUS COMPromise: LANGUAGE, LITERATURE, AND NATIONAL IDENTITY IN ALGERIA AND MOROCCO (1990).

36. GeORG LuKÁCS, History AND Class CONSCIOUSNESS: STUdiES IN MARXIST DIALECTICS 19 (Rodney Livingstone trans., Merlin Press, 1971). I have borrowed this phrase from Lukács, referring to Marx. Lukács' reference here is to politics, not fiction. The phrase is Lukács' evocation of dialectic, from an experiential standpoint. Most of Lukács' writing concerns novels, and his views on dialectic and history were central to his positions on literary realism. His phrase offers a deft rendering of fluid 
The resolute individualism of the ethnographies provides some access to these kinds of crisis, but ethnographers are only beginning to contemplate the possibility that an individual's life might be so fractured as to preclude a first-person rendering of his or her life course, or (for that matter) a steady narrative standpoint for the ethnographer him or herself. ${ }^{37}$

In one respect, the novels are more optimistic than the monographs, namely, in their consideration of the agentive aspects of knowledge itself. Knowing is not forgetting in the novels, as it sometimes is in the assimilation stories. Still, knowing is not necessarily saving, even in fiction. Where public discourse inserts a hyphen between identities, one refrain in the novels is the image of rending or explosion-"the crack in the world,"38 and "dark fissures in the globe light of the day" ${ }^{39}$ where the self and the public script break apart from the contending forces of selfknowledge and the image others hold. Another refrain is the figuration of the narrator as an author: The imaginary author presents narrative as confirmation of survival or (in more technical terms) confirmation of the limits of representation.

This is the context in which first-person narration is especially interesting - since it performs this critique. The critical burden of narrative performance in anti-racist fiction evokes the prose experiments of Fanon ${ }^{40}$ and DuBois ${ }^{41}$ who explicitly associate the necessity of first-person narrative with the limits of liberalism, and the condition of double consciousness. In their work, the techniques of realism and the critique of the limits of public discourse converge in an evocation of law's absence and (consequently) the imperative of self-representation. ${ }^{42}$ In modern fiction, too, the absence of law is sometimes specifically figured: as a presence-for example, as the policeman who will not be called, or the teacher who accuses unjustly; the slave-hunter, marauders, borders; or as an injury or a broken desire-physical and spiritual woundings, poverty, the beloved (a child, lover, or parent) who is missing, or cries for justice

states of consciousness-by definition elusive for ethnographers, $c f$. 1 JEAN COMAROFF \& JOHN L. COMAROFF, OF REVELATION AND REVOLUTION: CHRISTIANITY, COLONIALISM, AND CONSCIOUSNESS 27-32 (1991). I draw on his imagery-but not his implication in the argument as a whole that history is unidirectional. For discussion of dialectic and history in ethnographic terms, see 2 JEAN COMAROFF \& JOHN L. COMAROFF, OF REVELATION AND REVOLUTION: THE DIALECTICS OF MODERNITY ON A SOUTH AFRICAN FRONTIER 28-29 (1997).

37. E. Valentine Daniel, Charred lullabies: Chapters in an ANThropology of VIOLENCE (1996).

38. MORRISON, JAZZ, supra note 9, at 22-23.

39. WALKER, SECRET OF JOY, supra note 9, at 281.

40. FRANTZ FANON, BLACK SKIN, WHITE MASKS (Charles Lam Markmann trans., Grove Press 1967) (1952).

41. W. E. B. DuBols, The Souls Of Black Folk (Vintage 1990) (1903).

42. To anticipate the next Parts, it is significant that ASHCROFT, GRIFFTHS \& TIFFIN, supra note 29 , at $185-86$, are referring to postcolonial novels when they write: "The central problematic of [postcolonial] studies of writing is absence... the message 'event' occupies the apparent social fissure between the acts of writing and reading, the discursive space in which writer and readers as social actors never meet." 
that go unanswered. In these figurations of law's absence, first person narration is constructed as the law's textual Other.

As in the monographs, it is beside the point to ask what specific law has gone awry or what injury hurts the most. At the same time, the rejection of law is not a rejection of the social, nor of hope. The narrative structure and substance hold certain aspects of the social to one side, offering these back to the reader at critical moments. For example, in novels with first person narration the narrator's voice tends to monopolize the place of dialogue, displacing other representations of direct speech. Such dialogue between the fictional narrator and the (real) reader underscores the instability of "the real." As if in dialogue, an imaginary narrator offers his or her testimony. The real reader, listening in silence, receives this testimony and in so doing accepts a position of trust that is inherently also a (fictional? real?) position of power, freedom, and responsibility.

The ambiguity of this position is, I think, crucial to the agency that fiction offers readers. Writing, presented as a representation of narrative in a context of transference, makes reading into a counter-transference-offering readers an opportunity to respond from their personal capacity for identification and responsibility. Inescapably, this means setting aside any question of identity cast in racial, gendered, or other terms, at least as the first question. In this way, fiction makes the singular categories of identity within the contemporary state disappear-however momentarily-to yield place to the problem of knowledge and the capacity for love. ${ }^{43}$

The conclusion of Toni Morrison's Jazz makes this transference explicit; the first person narrator is the book itself-a speaking book that (who?) fuses writing and reading. ${ }^{44}$ The narrator (the book "itself") wistfully evokes a couple's "public love" and then says:

I envy them their public love. I myself have only known it in secret, shared it in secret and longed, aw longed to show it- to be able to say out loud what they have no need to say at all: That I have loved only you, surrendered my whole self reckless to you and nobody else. That I want you to love me back and show it to me. That I love the way you hold me, how close you let me be to you. I like your fingers on and on, lifting, turning. I have watched your face for

43. See BHABHA, supra note 3, at 190-91, for Bhabha's differentiation of Arendt's concept of agency, which he considers a repetitive mimesis "reified in the liberal vision of togetherness," from his suggestion that agency is contingent and temporal:

The process of reinscription and negotiation the insertion or intervention of something that takes on new meaning-happens in the temporal break in-between the sign, deprived of subjectivity, in the realm of the intersubjective. Through this time-lag $\longrightarrow$ the temporal break in representation-emerges the process of agency both as a historical development and as the narrative agency of historical discourse."

Id. at 191. I am suggesting that the ethnography "works" with an Arendtian notion of agency and that the fiction works by suspending the liberal vision of togetherness in favor of a more specific and personal experience of identification.

44. See TONI MORRISON, PLAYING IN THE DARK: WhITENESS AND THE LITERARY IMAGINATION, at xi-xiii (1992). 
a long time now, and missed your eyes when you went away from me. Talking to you and hearing you answer-that's the kick.

But I can't say that aloud; I can't tell anyone that I have been waiting for this all my life and that being chosen to wait is the reason I can. If I were able I'd say it. Say make me, remake me. You are free to do it and I am free to let you because look, look. Look where your hands are. Now." 45

Indeed, this very gesture (this proffering of agency to the reader within the narrative itself) is, in a sense, the novel's work. By this gesture, the fictional work displaces the very notion of singular identity-such as constitutes the federal menu of categories of race, ethnicity, gender, and sexual orientation-from the agentive realm. The identification fiction invites a reader to make with a speaking or writing subject does not await a sequel; it is its own transformative work. It does not directly empower the reader; in this, it is like ethnography. In contrast to ethnography, though, it gives the reader an experience of according agency to another by the fact of the reader's attentiveness. It does not matter that the other is fictional. The act of reading is real, just as the analyses that inform the stories are real, and the knowledge that make the stories matter is real, too. The agency of identification goes beyond comforting and understanding another person; it is an end in itself. But here, as in the ethnography, consciousness implies awareness of an actual sociolegal order. Fiction is not before or after the law, but perhaps in its fissures, or in its unsteady margins.

\section{LAW'S SILENCE}

U.S. ethnography, fiction, and civil rights law are easily distinguished by their different sites of production and modes of circulation. While all three offer important critiques of racism, they offer distinct substantive visions of anti-racism. At the risk of oversimplifying: Fiction offers a progressive vision anchored in expressive community; civil rights law-in the 1990s - offers a conservative vision anchored in the market; ethnography, for the most part, offers a centrist vision, firmly rooted to a liberal pluralist endorsement of diversity and its democratic potential. There is more to say about their substance, of course; I have emphasized the issue of narrative structure because it is at the level of structure that their differences can be put into dialogue most efficiently. That would be a dialogue about federal power, inequality, racism, and poverty, among other things. To reach this conversation from the ethnographies, we considered where and how the works' narrative structure is predicated on the wider context of the contemporary urban milieu. To reach it from the

45. MORRISON, JAZZ, supra note 38 , at 229. 
fiction, we considered the way authors-again, through narrative structure-choreograph specific displacements of federal policy discourse and key terms of public debate with a vindication of mutual recognition and self-expression in the public sphere.

Let us turn now to the public sphere of law, in the specific circumstances of the times. In 1989, a liberal Congress was pitched for a partisan contest with the conservative administration. Partisan divisions within the Congress ran deep. The last years of the Reagan administration had seen the Iran-Contra hearings and the defeat of the Bork nomination. The controversy over the Bork nomination illuminated the centrality of the judiciary in the field of partisan division during the Reagan years. But the confirmation process was not the only lightning rod for partisan politics within the federal government. Those partisan divisions were also, importantly, divisions among the branches of government, specifically over the expansion or containment of civil rights legislation. The contests took the form of debates over costs and profitability for American business in an increasingly transnational (global) economic order. My last example involves such a debate.

In 1990, Edward Kennedy, as Chair of the Senate Committee on Labor and Human Resources, opened hearings by announcing a project of reclaiming for the Congress a civil rights agenda that had been led offcourse (he claimed) by a conservative Supreme Court: "When the Court misinterprets the legislative intent of Congress, Congress can correct the mistake by enacting a new law. And that is what we intend to do." ${ }^{" 46}$ But that is precisely what they failed to do.

Although the would-be Civil Rights Act of 1990 was vetoed by President Bush, ${ }^{47}$ it suggests what was at stake in the hearings over a slightly earlier bill-the Americans with Disabilities Act of 1989 $(\mathrm{ADA})^{48}$ - which passed with bipartisan and administration support. The proposed safeguards for people with physical and mental disabilities were already guaranteed in 45 out of the 50 states; it had numerous co-sponsors from both sides of the aisle. Perhaps this made the ADA a useful context for rehearsing the arguments for a broader renewal of the civil rights agenda in the affirmative action context.

Like the proponents of the later Civil Rights Act of 1990, the proponents of the ADA evoked the Civil Rights Act of 1964 as their refrain. ${ }^{49}$ Indeed, the hearings on the ADA began on the twenty-fifth

46. Civil Rights Act: Hearings on S. 2104 Before the Comm. on Labor and Human Resources, 101 st Cong. 1 (1990) (statement of Sen. Edward M. Kennedy (Mass.), Chair, Senate Comm. on Labor and Human Resources).

47. See President's Message to the Senate Returning Without Approval the Civil Rights Act of 1990, 26 Weekly Comp. Pres. Doc. 1632 (Oct. 22, 1990) (vetoing S. 2104).

48. 42 U.S.C. $\S \S 12,1010-12,213$ (Supp. V 1993).

49. Americans with Disabilities Act: Hearing Before the Comm. on Small Business, 101 st Cong. 29 (1989) [hereinafter Hearings on Americans with Disabilities Act]. 
anniversary of the passage of Civil Rights Act of 1964, to the day. The invocations of the earlier law were broadly celebratory-notwithstanding the awkwardness of the constructed parallels between "race" and "disability." Congressman Moakley's statement is an example:

As you know, Mr. Chairman, the Civil Rights Act of 1964 prohibits employment discrimination on the basis of race, color, religion, sex, or national origin, but provides no protection for disabled workers. Handicapped individuals share a host of deprivations very similar to deprivations directed toward minority groups which are now protected under the CRA. Realizing the parallels between disabled individuals and minority groups, I strongly believe that the best way to combat flagrant discrimination is through a remedy which has proven successful in the past, the Civil Rights Act of $1964 .{ }^{50}$

Advocates of the ADA presented their support in terms of a range of identifications with specific experiences of disease and disability, with other groups who had historically experienced discrimination (e.g., Jews), and with universal problems such as old age. These opening statements in support of the bill were rhetorically keyed to other minority groups or to women. For example, Senator Tom Harkin said, "Today under our Nation's civil rights laws, an employer can no longer say to a prospective employee, 'I will not hire you because of the color of your skin, or because you are a woman, or because you are Jewish."'51 In some cases, these associations involved intertextual allusions to the slogans of other social movements, for example, Senator James Jeffords' invocation of "one simple right, the right to control their own lives, to make choices and to choose." 52 Senator Kennedy drew the widest circle:

I think, as you listen to those who have spoken today, you realize that there probably has not been a family in the country that has not been touched by some form of physical or mental challenge. . I bet if you go across this country, there really is not a member of a family or an extended family that has not been touched.

This legislation will become law... There is a movement and it is alive and it is growing. And it should grow.

50. Discrimination Against Cancer Victims and the Handicapped: Hearings Before the House Subcomm. On Employment Opportunities, 100th Cong., 3 (1987) [hereinafter Hearings on Discrimination] (statement of Rep. John Moakley (Mass.)) (emphasis added). Congressional documents regarding testimony on the Americans With Disabilities Act are reproduced and compiled in BERnaRd D. REAMS, JR., PETER J. MCGOVERN \& JON S. SCHUltZ, Disability LAW IN THE UNITED STATES: A LEgislative HistoRy OF THE AMERICANS WITH DiSABILITIES ACT OF 1990, PUBLIC LAW 101-336 (1992), a six volume documentary history of the Act. I cite them as separate government documents, since the pagination in REAMS, MCGOVERN \& SCHULTZ is not consecutive (instead reproduces pagination of the originals).

51. Americans with Disabilities Act: Joint Hearing on S. 2345 Before the Subcomm. on the Handicapped of the Comm. of Labor and Human Resources, 100th Cong. 8 (1988) (statement of Sen. Thomas Harkin (lowa)).

52. Id. at 20. (statement of Sen. James Jeffords (Vt.)). 
This legislation will become law. It will become law not because of the people up here, although all of us want it to become law, but because of you all across this Nation, in the small towns and communities, in the plants and factories all across this Nation, that are really challenging this country to ensure that we are basically going to have an even playing field and we are going to eliminate the barriers that keep people out, so that people can become a real part of the American dream..$^{53}$

The allusions to the legislative agenda of 1964-65 were highly literal. For example, Sandra Parrino, Chairperson of the National Council on the Handicapped, said in her testimony:

Martin Luther King had a dream. We have a vision. Dr. King dreamed of an America "where a person is judged not by the color of his skin, but by the content of his character." ADA's vision is of an America where persons are judged by their abilities and not on the basis of their disabilities; 36 million Americans, our Nation's largest and no longer silent minority. ${ }^{54}$

Congressman Tony Coelho later set the figure at 43 million, noting, "That is a tremendous political force." 55

The Reverend Jesse Jackson, president of the National Rainbow Coalition, spoke in favor of the bill, comparing the rights struggle of people with disabilities to that of the students in Tiananmen Square, and closer to home, the protest against the appointment of a hearing person to the presidency at Gallaudet College earlier that year (referred to by one witness as "our Selma"). ${ }^{56}$ Congressman Donald Payne spoke for the bill on behalf of the Congressional Black Caucus-in an eloquent statement also in support of the Civil Rights Act of 1990, which was emerging by then. ${ }^{57}$ The many other statements in this vein from Congressmen, Senators, and witnesses drew explicitly on the making of the Civil Rights Act of 1964, invoking the reality of justice, the urgency of inclusion, the practical benefits - political and economic - of extending full employment rights and other rights to people with disabilities. Those had been the arguments in 1964: Here, those principles were marshaled for service in both the ADA and the future Civil Rights Act of 1990.

Principle and pragmatics were compatible lines of argument only so long as these cost issues were beyond question. Advocates minimized costs, balancing them against overall gains to the economy-as civil rights

53. Id. at 17 (statement of Sen. Edward M. Kennedy (Mass.)).

54. Id. at 27 (statement of Sandra Parrino, Chairperson of the Nat'l Council on the Handicapped).

55. Id. at 36 (statement of Rep. Tony Coelho (Cal.)).

56. Id.at 4 ,

57. Hearings on Americans with Disabilities Act, supra note 49, at 15 (testimony of Rep. Donald Payne (N.J.), Member, Cong. Black Caucus) ("We must again place America on the right side of history with the passage of this omnibus civil rights statute."). 
advocates had in 1964. For example, a sympathetic Congressman Matthew Martinez raised the cost issue on the first day of the hearings in the opening question to Congressman Moakley, referring to "hav[ing] heard on several occasions ... that the cost would be prohibitive to providing access for these handicapped workers." ${ }^{\text {88 }}$ Moakley replied:

Well, actually we wouldn't expect an employer to build a certain type of entranceway to hire one employee in his plant. There might be a little cost of moving a desk from here to there or a machine, to give a certain entrance, but, Mr. Chairman, if you look at the overall picture, there would be one billion dollars more in the economy-

and he continued, elaborating the consequent reductions in welfare costs. ${ }^{59}$ As in the earlier era's contests over the Civil Rights Act of 1964, the defenders of the ADA argued that (in the words of Congressman Moakley) "[ $t]$ he contributions of disabled workers would clearly benefit our economy." 60

But precedent and principle were repeatedly confronted with cost questions. The rhetorical appeal to 1964 as the promise of universal rights now threatened to make any implementation of this new law seem uncontrollably expensive. Awkwardly, congressmen and witnesses sought to insert some distinctions within their earlier all-inclusive circles of potential beneficiaries. Congressman John LaFalce, Chair of the House Committee on Small Business, put it this way:

But there is a difference, is there not, in the type of discrimination? ... If you are discriminating against a woman or if you are discriminating against a minority, it is usually not going to involve the issue of expense on your part, is it? For some reason or another, you just do not want to deal with women or do not want to deal with minorities... . You are talking about the will, and you are talking about the mind really discriminating. ${ }^{61}$

Kenneth Lewis, representing the National Federation of Independent Business, sought to introduce some distinctions: "When I was attempting to study this bill, I was informed there are over 900 different disabilities the bill addresses. We need to have a definite understanding of what type of disabilities that we need expect [sic] provisions made for readily available accommodations." ${ }^{62}$ Another witness, Les Frieden, professor of rehabilitation at Baylor College, responded immediately: "Please forgive me as I do not intend to offend anyone, but there are over 900 shades of black and brown, and the law says you cannot discriminate on the basis of

58. Hearings on Discrimination, supra note 50, at 5 (statement of Rep. Matthew Martinez (Cal.)).

59. Id. (statement of Rep. Moakley).

60. Id. at 13 (statement of Rep. Moakley).

61. Hearings on Americans with Disabilities Act, supra note 49, at 29 (statement of Rep. John LaFalce (N.Y.), Chair, House Comm. on Small Business).

62. Id. at 42 (statement of Kenneth Lewis, representing Nat'l Fed'n of Indep. Bus.). 
color." ${ }^{33}$ To this, Congressman Jim Olin interjected:

I do not know. There are innumerable numbers of different types of disabilities. It would be endless, obviously. They are the same variety as we have people. But nevertheless there are some big categories that you are certainly going to want to be sure are covered such as putting a seat behind a post for a disabled person. Certainly you would not want that done. If that can be defined a little bit better or some kind of limits put on this, I think that you would find the business community much more amenable to trying it out for awhile and see how it works. ${ }^{64}$

Indeed, the expansion of the democratic appeal to identify people with disabilities as "everyone" raised, for some, the specter of endless litigation against businesses. Olin continued: "You do not want to end up in court all of the time. You do not want a great controversy. You want people to work out reasonable solutions." ${ }^{\prime 5}$ Joseph Dragonette, representing the U.S. Chamber of Commerce, encouraged this line of conversation, drawing a line between productive discussion of pragmatics and lofty talk of rights:

When you start using words like practical, that makes sense. It makes sense to me a lot more than words like undue burden or readily achievable... . Now let's specify those things that we can in the bill to make it understandable and workable for business. I mean this is not an opposing kind of thing. ${ }^{66}$

But the problem of fusing promise to practice-that is, of fusing democratic inclusiveness to costs-produced some awkward syntax. While improvised speech, especially under stress, is likely to produce infelicities, my interest in these crumbling sentence structures is in the way the fractures isolated significant key terms and/or stopped phrases short of lending full expression to the idea that equality should be limited by cost considerations - as in this passage from David Pinkus, testifying for a small business interest group:

You brought up the term full and equal and Mr. Frieden talked about the Astrodome. I agree that putting seats behind the posts is not within the spirit of what we are trying to achieve here. But when you say full and equal, this is one of the terms that we feel should be deleted from the bill. Because full and equal to me in relation to the Astrodome would mean that you have to provide all of the seats on the 50-yard line to accommodate wheelchairs. I mean you can carry some of these terms.

Full and equal. The term full is a pretty broad definition, and it

63. Id. (statement of Les Frieden, professor of rehabiliation at Baylor College).

64. Id. (statement of Rep. James Olin (Va.)).

65. Id.

66. Id. at 42-43 (statement of Joseph Dragonette, U.S. Chamber of Commerce). 
is not really defined. If you leave that up to the courts, some day somebody is going to say that means that every seat in the movie theater needs to accommodate disabled people. I am not sure that is what we are doing, or I am not sure that is what you are looking for either, and we just need to clarify that. ${ }^{67}$

As the democracy rhetoric confronted costs considerations, the fulsome invocations of citizenship and equal rights became more condensed. They crumbled to mere key phrases - especially the phrase "full and equal" drawn from the 1964 act and in play again in this context. For Congressman LaFalce, the cross-pressures arising from the universalistic appeal to democratic inclusion entailed in the 1964 law and the various current special interests yielded this lament (tellingly built on the rhetorical opposition of an able body and disabling legislation):

I want to assure you that every fiber in my body wants to see passage of a bill. But also, I have had such bad experiences with so many other laws. I do not trust anybody these days. I do not trust other Members of Congress or other committees because they come in and they say, oh, yes, we have thought of all these things, and then all of a sudden it is a law and you say, my God, I was relying upon you and you did not think about the most simple, basic elementary things....

Sure enough, once the law is being implemented there are a million and one horror stories. Unfortunately, this has more often been the rule than the exception with legislation... People do not want to be opposed to legislation that will deal with discrimination. ${ }^{68}$

Caught between a precedent that was beyond question and a set of challenges on the cost question, LaFalce could only lament the law itself and the lawmaking process (of which he was a part). This scissoring was precisely what scored the Civil Rights Act of 1990 with risk, contributing to its eventual defeat. The ADA, on the other hand, passed. The costs questions were handled with a series of phase-ins, limits on retroactive lawsuits, and adjustments of the requirements to the scale of the business in question.

The broader partisan debate over separation of powers at that time created a context in which democratic universalism could not be answered by the cost question. Instead, it was consumed by the question, leaving the speakers' syntax in a shambles, and the efficacy of legislation itself explicitly in doubt. One can literally (and literarily) hear the rights discourse yield to a market discourse in the following exchange between James Turner, Acting Assistant Attorney General in the U.S. Department of Justice Civil Rights Division, and Congressman Olin:

67. Id. at 43 (statement of David Pinkus) (emphasis added).

68. Id. at 55 (statement of Rep. LaFalce). 
Turner: Certainly, Mr. Chairman, there will be costs associated with this law. There are costs associated with not having this law that are at least as expensive.... To see wasted human resources is a very significant cost for our country.

Olin: I'm not arguing that point. Excuse me for interrupting you. I am talking about the potential of huge economic consequences and the need for putting some kind of a ceiling on that so we understand to what extent we are going to expect enterprises, public enterprises to respond to situations that they will be faced with.

Turner: I think that is true. The language that you quoted, the full and equal enjoyment of the accommodation or the facility, was drawn out of Title II of the Civil Rights Act of 1964. That has never-

Olin: I think that is a non sequitur all by itself. It is probably impossible to achieve that.

Turner: It may be.

Olin: Even as much as you might try. ${ }^{69}$

In this passage one can hear the production of silence-here, literally cutting off the speech of the witness at critical junctures where he presumably would have defended "full and equal" as necessitating costs. In unfinished statements such as these-and not in the content of the legislation alone - the contradictions between universal equality and the market took form. In the 1960 s, equality had been free, in market termseven efficient - as dual accommodations were merged for an integrated citizenry. In this context, though, the content of the legislation and its costs pulled in different directions, producing (or perhaps extending) the same fault line that makes the shifts of register among the genres so telling - and aligns them with the debate over the limits of federal power.

Authors and speakers in the different genres address the dynamics at the edges of this gap and attempt to cross it in characteristic ways, but the point to emphasize is that the genres themselves can be differentiated in terms of their emergence from and responses to the specific curtailments of liberalism in the 1990s. To address these, congressmen look to the market, novelists look to their readers' capacity for love, and ethnographers appeal to their readers through the allegorical potential of citizenship. Moreover, the gap between the ethnographic genres-divided by their placement of American communities and translocal or "largescale" institutions under separate rubrics-is also the gap within the other texts to which I have been referring. Indeed, the gap is to be found in the social field itself, as an ambiguous silence in the public sphere-even, as

69. Id. at 59-60 (statements of Rep. Olin and James Turner). 
my last example demonstrates, at the sentence level.

\section{CONCLUSION}

The silences within ethnography, and between fiction, ethnography, and lawmaking mark the places where-literally and figuratively-sentences begun as affirmations of civil rights cannot be completed in the language of costs. In saying this, I would not wish to be misunderstood as minimizing the pragmatic challenges of delivering equality or other conditions of reform. I acknowledge these, and for that very reason place neoliberalism at the center of the contemporary need to join cultural studies and sociolegal studies. Neoliberalism, in experiential terms, entails both the necessity and impossibility of maintaining a rights discourse that is not at some point vulnerable to questions of costs. This contradictory situation occasions realignments of power and the formation of new coalitions, as well as new social identities. ${ }^{70}$ It is also therefore at the center of ethnography's importance-the mode of inquiry par excellence for exploring the performative dimensions of culture that exceed the settled scripts of markets and legislation, among others. Interpretative ethnography is not everywhere shaped by the discourse of the state as I am claiming it (primarily) is in the community studies of the United States; however, its starting point is inevitably a hegemonic order against which ethnography lodges its critical specificity. In the contexts I have discussed in this Essay, interpretive ethnography reveals performative and discursive aspects of state power by its own textual practices, even when the state is not its object. Correspondingly, its textual limits trace the horizons where liberalism and citizenship are most sharply contradicted in the conditions of life.

The broad connections I have in mind between ethnography and the state are illustrated by Claude Lévi-Strauss, in his essay on "New York in 1941," a reminiscence of the war years. ${ }^{71}$ He recalls ethnic performances in the city-storytellers from Central and Eastern Europe, Chinese opera, an Indian in feathered headdress taking notes with a Parker pen in the New York Public Library-as fragile ephemera from a world on the wane:

Naturally, we sensed that all these relics were being assaulted by a mass culture that was about to crush and bury them-a mass culture that, already far advanced in America, would reach Europe a few decades later. This may be the reason so many aspects of life in New York enthralled us: it set before our eyes a list of recipes thanks to which, in a society each day ever more oppressive and inhuman, the

70. See ABU-LUGHOD, supra note 30; GREGORY, supra note 30; SANJEK, supra note 28; Roger Rouse, Thinking Through Transnationalism: Notes on the Cultural Politics of Class Relations in the Contemporary United States, 7 PUB. CULTURE 353 (1995).

71. Claude LÉvi-Strauss, New York in 1941, in THE VIEW from AFaR 258 (Joachim Neugroschel \& Phoebe Hoss trans., 1985) (1977). 
people who find it decidedly intolerable can learn the thousand and one tricks offered, for a few brief moments, by the illusion that one has the power to escape. ${ }^{72}$

Dressing up, dining out, these performances-as presented by LéviStrauss-provided ordinary men and women with a chance to enact their own presence (if only as arrival or imminent exit) on a stage of flavors, fabrics or folklore in the midst of the city, poised on the shore opposite the war. Today, under different circumstances, the ethnic palette-in politics, the media, and retailing-veils the distinction between arriving and staying, belonging and alienage, hegemony and resistance. ${ }^{73}$ The act of claiming identity is therefore always double-edged, and redactions of identity are themselves potent technologies of inclusion and exclusion. ${ }^{74}$

Difference conceived in these terms is not automatically a charter for pluralism, nor is the illusion of escape always so neatly contained within the bounds of the retail trade, where it can be fused with and confused for multicultural celebration. For some theorists, the move towards difference is an affirmative political movement, across a space of solidarity and contestation. ${ }^{75}$ It politicizes creativity and artistic innovation. ${ }^{76}$ Such signs are in wide circulation, linking the circuitries of juncture and disjuncture. Sometimes, difference signifies erotic space, ${ }^{77}$ or violence and outrage. ${ }^{78}$ It can be an object of highly fetishized power (I am thinking of the militias, the Klan, segregationists and separatists ${ }^{79}$; or the nourishment of vernacular ritual. ${ }^{80}$ In some contexts, it is a space of madness ${ }^{81}$ or addiction ${ }^{82}$; in others, it is a space for prayer.$^{83}$ For all of these, as for

72. Id. at 261 .

73. See Phyllis P. Chock, The Irony of Stereotypes: Towards an Anthropology of Eccentricity, 1 CUltURAL ANTHROPOLOGY 347 (1991); Bonnie Urciuoli, Acceptable Difference: The Cultural Evolution of the Model Ethnic American Citizen, in ETHNOGRAPHY AND DEMOCRACY: CONSTRUCTING IDENTITY IN MULTICULTURAL LIBERAL STATES 178 (Carol Greenhouse ed., 1998).

74. See Elizabeth Mertz, The Perfidy of Gaze and the Pain of Uncertainty: Anthropological Theory and the Search for Closure, in ETHNOGRAPHY IN UNSTABLE PLACES (Carol J. Greenhouse, Elizabeth Mertz \& Kay B. Warren eds., forthcoming 2002); see also Urciuoli, supra note 73; Hervé Varenne, Diversity as an American Cultural Category, in ETHNOGRAPHY AND DEMOCRACY, supra note 73 , at 27.

75. See Faye Ginsburg, Contested lives: THE Abortion Debate IN THE AMERican COMMUNITY (1989); MiCAELA di LEONARDO, EXoticS AT HOME: ANTHROPOlOGIES, OTHERS, American Modernity (1998); Homi Bhabha, Anxiety in the Midst of Difference, 21 POL. \& LEGAL ANTHROPOLOGY REV. 123 (1998).

76. See Paul Gilroy, The Black atlantic: Modernity and Double Consciousness (1993); Kathleen Stewart, a Space on the Side of the RoAd: Cultural Poetics in aN "OTHER" AMERICA (1996).

77. See, e.g., JEAN BAUdrillard, AMERICA 15 (Chris Tumer trans., Verso 1988).

78. See, e.g., Houston BAKER, Black STUdies, RAP AND THE ACADEMY (1993).

79. See, e.g., Paul hockenos, Free to Hate (1993); Catherine MCNicol Stock, Rural RADICALS: RIGHTEOUS RAGE IN THE AMERICAN GRAIN (1996).

80. See, e.g., BROWN, supra note 30.

81. See, e.g., Felix GUATTARI, ChaOSOPHY 80 (S. Lotringer ed., 1995).

82. See, e.g., BOURGOIS, supra note 15 . 
Lévi-Strauss, the illusion of escape positions a response to the discursive framework of the nation-state by reclaiming the significance of personal, physical presence. ${ }^{84}$

Without such associations with personal presence, "difference" would not have theoretical meaning or political resonance. But the empirical significance of difference is not inherent in the presence of particular groups "within" the nation. Rather, the discursive framework of citizenship creates the universal possibility of difference as a subject position vis-à-vis the state. ${ }^{85}$ These two meanings of difference (demography versus subjectivity) may be historically related (they are in the United States), and they may even unfold simultaneously in their respective or overlapping spheres. But they are very different, both as visions of pluralism and social justice, and as theoretical rationales for the human sciences. Lisa Lowe evokes these positions as an ambivalence in relation to the empirical life of the nation:

Cultural forms are not inherently "political," indeed in the modern nation-state, culture has been traditionally burdened to resolve what the political forms of the state cannot, but the contradictions that produce cultural differences are taken up by oppositional practices that are brought to bear on the political institutions that currently exist. Alternative cultural forms and practices do not offer havens of resolution but are rather often eloquent descriptions of the ways in which the law, labor exploitation, racialization, and gendering work to prohibit alternatives. Some cultural forms succeed in making it possible to live and inhabit alternatives in the encounter with those prohibitions; some permit us to imagine what we have still yet to live. ${ }^{86}$

This brings us back to the texts that are the main subject of this Essay. The constitution of "culture" within such ambiguous frameworks of possibility and prohibition is in itself a contextualization of the question of representation in the political spaces of the city, nation, and trans-nation. ${ }^{87}$ The breaks between genres (or, more accurately, the breaks that mark them as genres), as well as some of the tensions within the genres, may come to the page as silences (narrative breaks, evasions, or elisions). Such silences do not suspend questions of agency or the possibility of ethnography-any more than the fracture and isolation of urban neighborhoods in the United States or elsewhere in the midst of

83. See, e.g., Carol J. Greenhouse, Praying For Justice: Faith, Hope and CoMmunity IN AN AMERICAN TOWN (1986).

84. See Slavoj Žižek, "I Hear You with My Eyes": or The Invisible Master, in GAZE AND VOICE AS Love OBJECTS 90 (Renata Salecl \& Slavoj Žižek eds., 1996).

85. See Singh, supra note 7.

86. Lowe, supra note 6, at 19.

87. Cf. BRAH, supra note 5 . 
globalization suspend questions of responsibility or democratic aspiration. To the contrary, the silences reveal something of the impressive discursive compressions at the junctures of personal, local, national, and transnational power. These junctures are very immediate and concrete. As academics, we face them daily, even as readers and writers. Anthropologist Nicholas Dirks articulates the excitement and risk in the present moment:

The epistemological battles we fight are not mere abstract debates but struggles that take on their particular meanings in discrete and different terrains. Culture can be used to critique the West at the same time that it can be deployed to deflect any interrogation of local politics.... We are still uncertain about our place as intellectuals, and wherever we position ourselves, we are not completely sure what these places signify in relation to concerns of constituency and representation, let alone the politics of criticism. ${ }^{88}$

My purpose has been to suggest that the histories that produced the contemporary genres and their narrative forms-histories of movements and cross-currents in struggles for justice-have also produced the present complications to which Dirks refers. My main suggestion in this regard is that authors mobilize identification and agency differently through their texts, and that this aspect of their work articulates a "crisis of representation" that is more telling than issues of ethnographic authority or verisimilitude of social description. By attending to the relative literariness of our texts, we can pursue such issues and stakes, pushing ethnography farther toward the unsteady core of its necessity. I have considered fiction and law alongside ethnography, not just because we can borrow from our colleagues' creativity and craft to do more with words, but more specifically because key aspects of our craft and theirs are today molded to the shape of silence. That silence implicates federal power, in its present state of pressure and torque under conditions of globalization, and makes it a parameter of constructionist ethnography and interpretive approaches to texts.

The experiential horizons of federal power-past and present-in the subjective and material conditions of ordinary men's and women's lives, lend cultural studies its critical force. Interpretivism commits the human sciences to exploring the silent imprint of law's presence and absence for particular groups at particular times in the layeredness of texts and the association of textual practices with various publics. My purpose here has been to name that silence, trace some of its channels along the edges of liberalism, and explicitly connect the interpretivist commitment to commitments of other kinds.

88. Nicholas B. Dirks, In Near Ruins: Cultural Theory at the End of the Century, in IN NEAR Ruins: CUlTURAL THEORY AT THE END OF THE CENTURY 1, 15 (Nicholas B. Dirks ed., 1998). 
